\title{
Genotype-environment interaction, genetic trends, and performance dissimilarity of Nellore herds raised in three different environmental gradients
}

\author{
Interação genótipo $\mathrm{x}$ ambiente, tendências genéticas $\mathrm{e}$ \\ dissimilaridade do desempenho de rebanhos Nelore criados em três \\ gradientes ambientais distintos
}

\author{
Julio Cesar de Souza ${ }^{1 *}$; Fábio Rafael Leão Fialho ${ }^{2}$; \\ Marcos Paulo Gonçalves de Rezende ${ }^{3}$; Carlos Henrique Cavallari Machado4; \\ Mariana Pereira Alencar ${ }^{5}$; Carolina Fregonesi de Souza; \\ Paulo Bahiense Ferraz Filho ${ }^{7}$; André Luiz Julien Ferraz ${ }^{8}$
}

\begin{abstract}
The objectives of this work were to evaluate the genotype-environment interaction, and estimate genetic parameters, genetic trends, and performance dissimilarity-weight gain from birth to weaning (WGBW), adjusted weight to 205 days (W205), weight gain from weaning to 18 months of age (WG18), and adjusted weight to 550 days (W550)-in Nellore animals born between 1986 and 2012, and raised in pasture-based system in three different environmental gradients in Brazil. Data of 62,001 animals-11,729 raised in the Alto Taquari/Bolsão region (ATBR), 21,143 raised in the Campo Grande/Dourados region (CGDR) and 29,129 raised in the western São Paulo/Paraná region (SPPR) in Brazil-were used. The contemporary groups were defined by sex, location, and birth year and season, with at least nine individuals, two different environments, and breeding bulls with at least five progenies. The statistical model contained the direct additive and residual genetic effects (random effects), and environmental and contemporary group effects (fixed effects). Genetic parameters, genotype-environment interaction and genetic trends were estimates using animal model (uni- and/or bi- traits). The level of similarity between regions was evaluated using principal components. The animals raised in the CGDR had superior performance regarding the traits evaluated. The direct heritability estimates ranged from 0.39 to 0.44 (WGBW), 0.41 to 0.45 (W205), 0.42 to 0.55 (WG18) and 0.60 to 0.62 (W550). The maternal heritability of the traits ranged from 0.20 (WGBW), 0.12 to 0.18 (W205), 0.00 to 0.06 (WG18) and 0.02 to 0.22 (W550). According to the Spearman correlation, the ranking of the breeding bulls in the regions evaluated were different. The mean of Euclidean distance indicated low similarity between ATBR and CGDR (43.20), and ATBR and SPPR (29.24). CGDR and SPPR presented similarity of 17.84. The breed values increased over the years in the traits evaluated. The cumulative variance percentage of the first two main components explained $99.99 \%$ variation among the regions, and the weight gains of the animals were the most important to differentiate the regions. A genotype-environment interaction was found for the traits evaluated, thus, the breeding bull selected with superior genetic merit for one region might not be the best for others.
\end{abstract}

Key words: Principal components. Environmental effect. Genetic parameters. Genetic progress. Zebu.

${ }^{1}$ Prof. Titular, Universidade Federal de Mato Grosso do Sul, UFMS, Campo Grande, MS, Brasil. E-mail: julio.souza@ufms.br

2 Discente, UEMS, Aquidauana, MS, Brasil. E-mail: fabiolfialho@hotmail.com

3 Doutorando, Universidade Estadual do Sudoeste da Bahia, UESB, Itapetinga, Bahia, Brasil. E-mail: mpgrezende@gmail.com

${ }^{4}$ Prof., Faculdades Associadas de Uberaba, UBERABA, MG, Brasil. E-mail: carlos.machado@gmail.com

5 Pesquisador, Associação Brasileira de Criadores de Zebu, ABCZ, UBERABA, MG, Brasil. E-mail: mariana.alencar@gmail.com

Discente, Universidade Federal do Pampa, UNIPAMPA, Uruguaiana, RS, Brasil. carolinafregonesi7@hotmail.com

Prof. Titular, UFMS, Três Lagoas, MS, Brasil E-mail: paulo.ferraz@ufms.br

8 Prof. UEMS, Aquidauana, MS, Brasil. E-mail: splinter@uems.br

Author for correspondence 


\section{Resumo}

O objetivou-se avaliar as existências de interação genótipo x ambiente, estimar os parâmetros genéticos, tendências genéticas e dissimilaridade para o ganho de peso do nascimento a desmama (GPND), peso ajustado para os 205 dias (P205), ganho de peso da desmama aos 18 meses de idade (GP18) e peso ajustado aos 550 dias em animais da raça Nelore nascidos entre os anos de 1986 a 2012 e criados a pasto em três gradientes ambientais distintos no Brasil. Utilizou-se informações de 62001 animais: 11729 criados na região do Alto Taquari- Bolsão (RATB), 21143 animais na região de Campo Grande-Dourados (RCGD) e 29129 animais na região Oeste de São Paulo-Paraná (RSPR). Os grupos contemporâneos foram compostos por sexo, fazenda, estação e ano de nascimento dos animais; tendo no mínimo nove indivíduos; cada reprodutor tinha no mínimo cinco filhos e encontravam-se em pelo menos dois ambientes diferentes. O modelo estatístico continha os efeitos genéticos aditivo direto e residual (efeitos aleatórios) e, como fixos, efeitos de fazenda e grupo de contemporâneos. Estimouse parâmetros genéticos, interação genótipo x ambiente e tendências genéticas (modelo animal uni e bi característica). Avaliou-se o grau de similaridade entre as três regiões utilizando componentes principais. Animais criados na região de RCGD apresentam superioridade para as características de desempenho avaliadas. As estimativas de herdabilidades direta variaram entre: 0,39 a 0,$44 ; 0,41$ a 0,45 ; 0,42 a 0,55 e 0,60 a 0,62 respectivamente para GPND, P205, GP18 e P550. Para herdabilidade materna para as mesmas características, variaram entre: 0,$20 ; 0,12$ a 0,$18 ; 0,00$ a 0,06 e 0,02 a 0,22 . Com base na correlação de Spearman constatou-se alteração na classificação dos reprodutores por região. A distância euclidiana média indicou menor similaridade da RATB com RCGD $(43,20)$ e RSPR $(29,24)$; para RCGD e RSPR o valor de similaridade foi 17,84. Ocorreu aumento nos valores genéticos ao longo dos anos nas características. Os dois primeiros componentes apresentaram percentual de variância acumulada suficiente para justificar $99,99 \%$ da variação entre as regiões, sendo que os ganhos de pesos dos animais, apresentaram maior importância para a diferenciação das regiões. Conclui-se que há existência de interação genótipo $\mathrm{x}$ ambiente para as características avaliadas, havendo possibilidade dos reprodutores selecionados como de mérito genético superior para uma região não o serem para outras. Palavras-chave: Componentes principais. Efeito ambiental. Parâmetros genéticos. Progresso genético. Zebu.

\section{Introduction}

Increasing the weight gain performance and reducing the time the cattle spend in the pasture increase the rotation of animals and reduce the time for slaughter, thus, more animals can be finished in the area per unit of time (LOPES et al., 2012). Growth precocity has been emphasized among the criteria for selection in many beef cattle breeding programs (PEDROSA et al., 2014), due to its potential for genetic gains per generation, since it has moderate heritability (LIRA et al., 2013; REZENDE et al., 2014).

Brazil has great diversity of environments and production systems; thus, the performance response of the genotypes can be different (HERRERO et al., 2010; JOOST et al., 2010). Other non-genetic factors such as sex, and birth year and season must also be considered in genetic evaluations (SOUZA et al., 2004; RAMOS et al., 2009). According to Ambrosini et al. (2016), estimates of breed value and heritability increase with environmental improvement, allowing genetic gains and selection of the best genotypes. This confirms the need for evaluating growth differences in cattle in different environmental gradients. Several authors reported that the weighting of the genotype-environment interaction increases genetic gains (FRIDRICH et al., 2008; SILVEIRA et al., 2014; SOUZA et al., 2008).

Multivariate analysis can be efficient for selecting breeding bulls considering different traits in different environmental gradients. This analysis attempts to explain the maximum variation between effects (REZENDE et al., 2016), rewriting the coordinates of the samples in another axis system that is more convenient for data analysis (REZENDE 
et al., 2017), while evaluating the importance of the original variables with more importance from a statistical point of view (MOITA NETO; MOITA, 1998). Moreover, studying the genetic trends of a population is essential to evaluate whether the selection programs adopted are progressing satisfactorily, contributing to guiding future actions (MALHADO et al., 2008; PASSAFORO et al., 2016).

In this context, the objectives of this work were to evaluate the genotype-environment interaction, and estimate genetic parameters, genetic trends, and performance dissimilarity-weight gain from birth to weaning (WGBW), adjusted weight to 205 days (W205), weight gain from weaning to 18 months of age (WG18), and adjusted weight to 550 days (W550)-in Nellore animals born between 1986 and 2012, and raised in pasture-based system in three different environmental gradients in Brazil.

\section{Material e Methods}

Information on 62,001 animals-11,729 raised in the Alto Taquari/Bolsão region (ATBR), 21,143 raised in the Campo Grande/Dourados region (CGDR) and 29,129 raised in the western São Paulo/Paraná (SPPR) in Brazil-were used. This information consisted of 88,463 data of Nellore cattle born between 1986 and 2012 and raised in extensive systems-16.914 from ATBR, 28.404 from CGDR and 43.145 SPRR. These data are from the National Zootechnical Archive (zebu breeds) and were provided by the Brazilian Association of Zebu Breeders (ABCZ). Table 1 shows the number of animals evaluated-breeding bulls, dams, and contemporary groups. The production regions used were characterized and differentiated by Arruda and Sugai (1994) according to their production system, technology level, quality and productivity of the resources, and breed of the cattle herd (Table 2).

Table 1. Number of breeders, dams, and contemporary group for birth weight at weaning (WGBW), adjusted weight to 205 days (W205), weaning weight gain at 18 months of age (WG18) and adjusted weight to 550 days (W550) of Nellore herds raised in three different environmental gradients.

\begin{tabular}{ccccccccccccc}
\hline \multirow{2}{*}{ Region } & \multicolumn{3}{c}{ WGBW $(\mathrm{Kg})$} & \multicolumn{3}{c}{ W205 $(\mathrm{kg})$} & \multicolumn{3}{c}{ WG18 $(\mathrm{kg})$} & \multicolumn{3}{c}{ W550 $(\mathrm{kg})$} \\
\cline { 2 - 13 } & REP & DAM & CG & REP & DAM & CG & REP & DAM & CG & REP & DAM & CG \\
\hline ATBR & 824 & 10,905 & 363 & 824 & 10,905 & 363 & 824 & 10,905 & 363 & 824 & 10,905 & 363 \\
CGDR & 1,049 & 20,094 & 565 & 1,049 & 20,094 & 565 & 1,049 & 20,094 & 565 & 1,049 & 20,094 & 565 \\
SPPR & 1,036 & 28,093 & 588 & 1,036 & 28,093 & 588 & 1,036 & 28,093 & 588 & 1,036 & 28,093 & 588 \\
Total & & 59,092 & 1,516 & & 59,092 & 1,516 & & 59,092 & 1,516 & & 59,092 & 1,516 \\
\hline
\end{tabular}

$\mathrm{REP}=$ number of breeding animals evaluated by region; $\mathrm{CG}=$ contemporary groups; ATBR $=$ Alto Taquari/Bolsão region $(\mathrm{N}=$ 11729); CGDR = Campo Grande-Dourados ( $=21143) ;$ SPPR = Western São Paulo - Paraná $(\mathrm{N}=29129)$.

The weight gain from birth to weaning (WGBW), adjusted weight to 205 days (W205), weight gain from weaning to 18 months of age (WG18), and adjusted weight to 550 days (W550) of the animals were evaluated. The animals whose weight (W205 and W550) were higher or lower than 3-fold the deviation from the mean were discarded. The WGBW was calculated by the equation $W G B W=$ (W205 - WB) / 205. WG18 was calculated by the equation $W G 18=(W 550-W 205) /(I 550-I 205)$. The contemporary groups were defined by sex, farm, and birth year and season, with at least nine individuals per group. All breeding bulls had at least five progenies in at least two contemporary groups.

Breeding values were estimated using the derivative-free restricted maximum likelihood (DFREML), obtained by the equations of the Henderson mixed models, and the best linear unbiased prediction (BLUP), in the Multiple Trait Derivative-Free Restricted Maximum Likelihood (MTDFREML) program (BOLDMAN et al., 1995). Single and bi traits analyses were used. 
The statistical model included the fixed effects of contemporary groups-sex, farm, and birth year (1986 to 2012) and season (rainy: October to April; dry: May to September); the dam's age at calving as covariate (linear and quadratic); and the random effects of the animal (direct genetic), dam (maternal genetic), permanent environment, and environmental (residual). The expected progeny differences $(E P D)$ was obtained by dividing the predicted breed value by two.

Table 2. Characterization of the three Brazilian regions evaluated: Alto Taquari/Bolsão (ATBR), Campo Grande/ Dourados (CGDR), and western São Paulo/Paraná (SPPR).

\begin{tabular}{|c|c|c|c|}
\hline & ATBR & CGDR & SPPR \\
\hline Location & $\begin{array}{l}\text { Highlands of the state of } \\
\text { South of Mato Grosso; } \\
\text { within part of the Paraná } \\
\text { and Paraguay basins; with a } \\
\text { predominant slightly wavy } \\
\text { topography (chapadão) }\end{array}$ & $\begin{array}{l}\text { Predominant flat and } \\
\text { slightly wavy topography, } \\
\text { except in the Bodoquena } \\
\text { micro-region, which has } \\
\text { a more varied relief. The } \\
\text { Maracaju mountains, in the } \\
\text { Bodoquena micro-region, } \\
\text { divide the Paraná and Para- } \\
\text { guay basins. }\end{array}$ & $\begin{array}{l}\text { The predominant relief was } \\
\text { modeled in sedimentary } \\
\text { rocks from the Mesozoic } \\
\text { basin of the Paraná River, } \\
\text { presenting altitudes of } 250 \\
\text { to } 300 \mathrm{~m} \text {. The main com- } \\
\text { ponents of its hydrographic } \\
\text { network are the Paraná } \\
\text { River and its tributaries. }\end{array}$ \\
\hline Topography & Slightly wavy & Flat to Slightly wavy & $\begin{array}{l}\text { Modeled in sedimentary } \\
\text { rocks; plateau }\end{array}$ \\
\hline Climate & $\begin{array}{l}\text { Sub-hot humid, with three } \\
\text { dry months (June to Au- } \\
\text { gust) }\end{array}$ & $\begin{array}{l}\text { Sub-hot humid with two to } \\
\text { three dry months (June to } \\
\text { August) }\end{array}$ & Tropical \\
\hline Annual Precipitation & $1,250 \mathrm{~mm}$ & 1,250 a $1,500 \mathrm{~mm}$ & $1,250 \mathrm{~mm}$ \\
\hline Soil & $\begin{array}{l}\text { Predominance of quartz } \\
\text { dystrophic sands of low } \\
\text { fertility }\end{array}$ & $\begin{array}{l}\text { Oxisol (dark-Red and } \\
\text { Purple Latosol) of medium } \\
\text { to good fertility }\end{array}$ & $\begin{array}{l}\text { Oxisol (Purple dark-Red } \\
\text { or podzolic Red-Yellow } \\
\text { Latosol) of medium to high } \\
\text { fertility }\end{array}$ \\
\hline Natural Vegetation & Savannah & $\begin{array}{l}\text { Savannah, clear fields, and } \\
\text { semideciduous forests }\end{array}$ & $\begin{array}{l}\text { Tropical semideciduous } \\
\text { forests }\end{array}$ \\
\hline
\end{tabular}

The effect of the genotype-environment interaction was evaluated by bi-trait's analysis considering the same trait expressed in two different regions and determined by the same groups of genes. It was also evaluated by changing the classification order of the sires based on the expected progeny differences regarding the trait's WGBW, W205, WG18 and W550 evaluated by comparing the regions, and considered as being different trait. Subsequently, the sires were ranked by their expected progeny differences.

The model used in the matrix form was $y=X \beta$ $+Z g+M m+W p e+e$, wherein $y$ is the vector of the dependent variables (WGBW, W205, WG18, W550); $\beta$ is the vector of the fix effects, including contemporary groups; $X$ is the matrix of incidence associating $\beta$ and $y ; g$ is the vector of random effects of the animal's direct additive breed value; $Z$ is the matrix of incidence associating $g$ and $y ; m$ is the vector of random effects of the maternal additive breed value; $M$ is the matrix of incidence associating $m$ and $y$; pe is the vector of random effects of the dam's permanent environment; $W$ is the matrix of incidence associating $p$ and $y$; and $e$ is the vector of residual effects. 
The estimation of the covariance components was obtained by the DFREML, through the uni-trait animal model, using the MTDFREML program. Spearman correlations were used to evaluate the ranking of bulls in the three regions, thus assessing the classification similarities of the sires between regions, using the SAS program. Genetic trends were estimated by analyzing the regression of the animals' breed values by year of birth, using the SAS program (2015). Subsequently, it was evaluated using the similarity levels between regions using principal components analysis (HAMMER et al., 2001), identifying similar groups with biplot dispersion graphs; the mean Euclidean analysis was used to verify the distances between regions. Variance analysis was performed (SAS, 2015) to verify the existence of differences between regions. The model used contained the region and contemporary group fixed effects, the random effects of sire and error, and the dam's age at calving covariable (linear and quadratic).

\section{Results and Discussion}

All sources of variation included in the modelcomparison of differences between the traits by regions-were significant $(p<0.05)$. The WGBW, W205, WG18 and W550 means in the CGDR was higher than in the other regions (Table 3).

Table 3. Descriptive statistics for birth weight at weaning (WGBW), adjusted weight to 205 days (W205), weaning weight gain at 18 months of age (WG18) and adjusted weight to 550 days (W550) of Nellore herds raised in three different environmental gradients.

\begin{tabular}{lcccccccc}
\hline \multirow{2}{*}{ Região } & \multicolumn{2}{c}{ WGBW } & \multicolumn{2}{c}{ W205 } & \multicolumn{2}{c}{ WG18 } & \multicolumn{2}{c}{ W550 } \\
\cline { 2 - 8 } & Mean \pm SD & CV $(\%)$ & Mean \pm SD & CV $(\%)$ & Mean \pm SD & CV $(\%)$ & Mean \pm SD & CV $(\%)$ \\
\hline ATBR & $0.716 \pm 0.13 \mathrm{C}$ & 17.67 & $177.39 \pm 26.26 \mathrm{C}$ & 14.80 & $0.358 \pm 0.13 \mathrm{C}$ & 35.86 & $301.06 \pm 51.27 \mathrm{C}$ & 17.03 \\
CGDR & $0.745 \pm 0.13 \mathrm{~A}$ & 17.77 & $183.72 \pm 27.45 \mathrm{~A}$ & 14.94 & $0.381 \pm 0.13 \mathrm{~A}$ & 33.62 & $315.34 \pm 53.25 \mathrm{~A}$ & 16.89 \\
SPPR & $0.731 \pm 0.13 \mathrm{~B}$ & 17.86 & $180.71 \pm 27.12 \mathrm{~B}$ & 15.01 & $0.379 \pm 0.13 \mathrm{~B}$ & 35.48 & $311.59 \pm 54.45 \mathrm{~B}$ & 17.48 \\
\hline
\end{tabular}

$\mathrm{SD}=$ standard deviation; $\mathrm{CV}=$ Coefficient of variation; $\mathrm{ATBR}=$ Alto Taquari/Bolsão region; $\mathrm{CGDR}=$ Campo Grande-Dourados; SPPR = Western São Paulo-Paraná.

The effect of the medium on the productive traits of the Nellore cattle was also found by Souza et al. (2000) and Conceição et al. (2005). This indicates that the breeder must pay attention in selecting breeding bulls, since the animals can have different performances from one region to another. This must be especially considered in unfavorable environments, where identify the best animals is difficult, and in superior environments, avoiding misuse of breeding bulls (AMBROSINI et al., 2016). Thus, correcting the weights and weight gain of the animals, the animal's age, and the dam's age at calving is indicated (SOUZA et al., 2000; FERRAZ FILHO et al., 2002; FRIDRICH et al., 2008) during selection. Genetic covariance between the direct and maternal additive genetic effects were negative for WGBW and W205 in all three environmental gradients (Table 4).

This indicates that dams resulting from the best sires are not necessarily the best dam. However, this estimate may be biased due to the evaluation through the arrangement of the proposed model. Diop et al. (1999) inserted the effects of granddam into the model (animal model) with maternal effects, and stated that the negative genetic correlation between the direct and maternal effects could be related to the environmental conditions in which the animals were managed.

Meyer (1992), Souza et al. (1998), Fernandes and Ferreira (2000), Carvalho et al. (2013), Lacerda et al. (2014) and Santos et al. (2012) evaluated beef 
cattle using field data and found also negative genetic correlations between direct and maternal effects. This should only be done when the data supports the model's settings. This genetic antagonism has been considered in genetic evaluations to estimate many parameters in beef cattle. However, Malhado et al. (2004) and Cundiff (2016) avoided this problem by using the direct-maternal correlation as zero in the evaluation. According to Schaeffer (1984), effects of correlation values with bias in multivariate analyzes increase the prediction error variance. Moreover, Henderson (1975) stated that the use of variances and an incorrect covariance matrix in the mixed model increases the prediction error variance.

Table 4. Components of covariance and environmental components for birth weight at weaning (WGBW), adjusted weight to 205 days (W205), weaning weight gain at 18 months of age (WG18) and adjusted weight to 550 days (W550) of Nellore herds raised in three different environmental gradients.

\begin{tabular}{|c|c|c|c|c|c|c|c|c|c|}
\hline \multirow{2}{*}{ Region } & \multirow{2}{*}{ Item } & \multicolumn{8}{|c|}{ Traits } \\
\hline & & \multicolumn{2}{|c|}{ WGBW } & \multicolumn{2}{|c|}{ W205 } & \multicolumn{2}{|c|}{ WG18 } & \multicolumn{2}{|l|}{ W550 } \\
\hline \multirow{5}{*}{ ATBR } & $\boldsymbol{\sigma}_{\mathrm{a}}^{2}$ & \multicolumn{2}{|c|}{0.0055} & \multicolumn{2}{|c|}{220.84} & \multicolumn{2}{|c|}{0.0065} & \multicolumn{2}{|l|}{1091.57} \\
\hline & $\boldsymbol{\sigma}_{\mathrm{m}}^{\mathrm{a}^{\mathrm{a}}}$ & \multicolumn{2}{|c|}{0.0025} & \multicolumn{2}{|c|}{112.98} & \multicolumn{2}{|c|}{0.0000} & \multicolumn{2}{|l|}{35.33} \\
\hline & $\boldsymbol{\sigma}_{\mathrm{am}}$ & \multicolumn{2}{|c|}{-0.0004} & \multicolumn{2}{|c|}{-74.7975} & \multicolumn{2}{|c|}{0.0000} & \multicolumn{2}{|l|}{0.0000} \\
\hline & c & 0.01700 & \pm 0.04 & 0.05400 & $\pm \quad 0.027$ & 0.01300 & \pm 0.00 & $0.00002 \pm$ & 0.02 \\
\hline & $\mathrm{e}^{2}$ & 0.38000 & \pm 0.04 & 0.46000 & $\pm \quad-0.03$ & 0.45000 & \pm 0.02 & $0.38000 \pm$ & 0.02 \\
\hline \multirow{5}{*}{ CGDR } & $\boldsymbol{\sigma}_{\mathrm{a}}^{2}$ & \multicolumn{2}{|c|}{0.0062} & \multicolumn{2}{|c|}{272.43} & \multicolumn{2}{|c|}{0.0054} & \multicolumn{2}{|l|}{1281.57} \\
\hline & $\sigma_{m}^{2}$ & \multicolumn{2}{|c|}{0.0028} & \multicolumn{2}{|c|}{107.45} & \multicolumn{2}{|c|}{0.0008} & \multicolumn{2}{|l|}{453.83} \\
\hline & $\boldsymbol{\sigma}_{\mathrm{am}}$ & \multicolumn{2}{|c|}{-0.0003} & \multicolumn{2}{|c|}{-78.6599} & \multicolumn{2}{|c|}{0.0000} & \multicolumn{2}{|c|}{-297.1294} \\
\hline & $c^{a m}$ & 0.00054 & \pm 0.034 & 0.05700 & \pm 0.022 & 0.00530 & \pm 0.016 & $0.00000 \pm$ & 0.02 \\
\hline & $\mathrm{e}^{2}$ & 0.37000 & \pm 0.029 & 0.44000 & \pm 0.025 & 0.51000 & \pm 0.019 & $0.30000 \pm$ & 0.03 \\
\hline \multirow{5}{*}{ SPPR } & $\overline{\sigma_{a}^{2}}$ & \multicolumn{2}{|c|}{0.0054} & \multicolumn{2}{|c|}{250.87} & & 065 & 1453.02 & \\
\hline & $\boldsymbol{\sigma}_{\mathrm{m}}^{\mathrm{a}}$ & & 028 & 116 & & & 008 & 483.44 & \\
\hline & $\sigma_{\mathrm{am}}$ & -0 & 005 & -83 & 506 & & 000 & -437.124 & \\
\hline & $c^{\text {dilt }}$ & 0.02700 & \pm 0.031 & 0.07600 & \pm 0.02 & 0.07500 & \pm 0.01400 & $0.06500 \pm$ & 0 \\
\hline & $\mathrm{e}^{2}$ & 0.42000 & \pm 0.024 & 0.46000 & \pm 0.02 & 0.44000 & \pm 0.01600 & 0.30000 & 0 \\
\hline
\end{tabular}

$\overline{\mathrm{ATBR}}=$ Alto Taquari/Bolsão region; $\mathrm{CGDR}=$ Campo Grande-Dourados; SPPR $=$ Western São Paulo-Paraná. $\sigma^{2}=$ additive genetic variance; $\boldsymbol{\sigma}_{\mathrm{m}}^{2}=$ maternal genetic variance; $\boldsymbol{\sigma}_{\mathrm{am}}=$ maternal additive covariance; $\mathrm{c}=$ permanent environment; $\mathrm{e}^{2}=$ proportion of environmental variance over the phenotypic variance.

The direct heritability for WGBW and W205 indicated a possibility of good genetic gain (Table 5). The estimated direct heritability for WGBW in the ATBR and CGDR were similar, and higher than that of the SPPR. The W205 estimates in the ATBR and SPPR had similar heritability, indicating that genetic selection for W205 would present a rapid response-animals with a high mean $\mathrm{h}^{2}$ respond well to selection, promoting a faster direct gain.

Maternal heritability $\left(\mathrm{h}^{2} \mathrm{~m}\right)$ for WGBW and W205 had medium magnitude- 0.18 to 0.21 . The direct heritability estimated for the WG18 in the three regions confirm the results found by Marques et al. (2013). The direct heritability estimated for W550 confirm the results found by Santos et al. (2012) in northern Brazil (0.33 for W205, 0.51 for P365 and 0.41 for W550), and Lira et al. (2013), who evaluated genotype-environment interaction in post-weaning Nellore cattle raised in the states of Maranhão, Mato Grosso, and Pará (0.54, 0.26, 0.41 for W365; and $0.80,0.24,0.80$ for W550, respectively). 
The genetic correlations found for a same trait in different environments indicate that the genes responsible for the expression of performance traits in one region are not the same in another region. According to Robertson, (1952) and Souza et al. (2003), a genetic correlation less than 0.80 for the same trait in different environments indicates a genotype-environment interaction. The genetic correlation for W550 in ATBR and SPPR was 0.46. According to the results found (Table 6), the expression of approximately $40 \%$ genes responsible for WGBW, W205, WG18 and W550 were different between environments, thus representing different responses to selection.

Table 5. Estimates of direct $\left(h^{2} a\right)$ and maternal $\left(h^{2} m\right)$ heritability for the birth weight at weaning (WGBW), adjusted weight to 205 days (W205), weaning weight gain at 18 months of age (WG18) and adjusted weight to 550 days (W550) of Nellore herds raised in three different environmental gradients.

\begin{tabular}{|c|c|c|c|c|c|}
\hline \multirow{2}{*}{ Region } & \multirow{2}{*}{ Item } & \multicolumn{4}{|c|}{ Traits } \\
\hline & & WGBW & W205 & WG18 & W550 \\
\hline \multirow{3}{*}{ ATBR } & $\mathrm{h}^{2}$ & $0.44 \pm 0.04$ & $0.41 \pm 0.04$ & $0.55 \pm 0.03$ & $0.60 \pm 0.03$ \\
\hline & $\mathrm{h}^{2}{ }_{\mathrm{m}}^{\mathrm{a}}$ & $0.20 \pm 0.05$ & $0.21 \pm 0.05$ & $0.00 \pm 0.01$ & $0.02 \pm 0.02$ \\
\hline & $r_{a m}$ & $-0.11 \pm 0.09$ & $-0.47 \pm 0.07$ & $0.00 \pm 0.00$ & $0.00 \pm 0.00$ \\
\hline \multirow{3}{*}{ CGDR } & $\begin{array}{c}\mathrm{am}^{2} \\
\mathrm{~h}_{\mathrm{a}}\end{array}$ & $0.44 \pm 0.04$ & $0.45 \pm 0.03$ & $0.42 \pm 0.02$ & $0.62 \pm 0.04$ \\
\hline & $\mathrm{h}^{2}{ }_{\mathrm{m}}^{\mathrm{a}}$ & $0.20 \pm 0.04$ & $0.18 \pm 0.04$ & $0.06 \pm 0.02$ & $0.22 \pm 0.04$ \\
\hline & $\mathrm{r}_{\mathrm{am}}$ & $-0.06 \pm 0.07$ & $0.03 \pm 0.06$ & $0.00 \pm 0.00$ & $-0.39 \pm 0.05$ \\
\hline \multirow{3}{*}{ SPPR } & $\mathrm{h}^{2}{ }_{\mathrm{a}}$ & $0.39 \pm 0.03$ & $0.41 \pm 0.03$ & $0.44 \pm 0.02$ & $0.62 \pm 0.00$ \\
\hline & $\mathrm{h}_{\mathrm{m}}{ }^{\mathrm{a}}$ & $0.20 \pm 0.04$ & $0.19 \pm 0.04$ & $0.05 \pm 0.02$ & $0.21 \pm 0.00$ \\
\hline & $r_{a m}$ & $-0.13 \pm 0.06$ & $-0.49 \pm 0.05$ & $0.00 \pm 0.00$ & $-0.52 \pm 0.00$ \\
\hline
\end{tabular}

ATBR $=$ Alto Taquari/Bolsão region; CGDR $=$ Campo Grande-Dourados; SPPR = Western São Paulo-Paraná. $\mathrm{h}^{2}{ }_{\mathrm{a}}=$ heritability of direct additive effect; $\mathrm{h}_{\mathrm{m}}^{2}=$ heritability of maternal effect; $\mathrm{r}_{\mathrm{am}}=$ genetic correlation of direct and maternal additive effect.

Table 6. Estimates of genetic correlations for the birth weight at weaning (WGBW), adjusted weight to 205 days (W205), weaning weight gain at 18 months of age (WG18) and adjusted weight to 550 days (W550) of Nellore herds raised in three different environmental gradients.

\begin{tabular}{lcccc}
\hline \multirow{2}{*}{\multicolumn{1}{c}{ Region }} & \multicolumn{3}{c}{ Traits } \\
\cline { 2 - 5 } & WGBW & W205 & WG18 & W550 \\
\hline ATBR-CGDR & 0.62 & 0.57 & 0.60 & 0.57 \\
ATBR-SPPR & 0.57 & 0.69 & 0.59 & 0.46 \\
CGDR-SPPR & 0.63 & 0.56 & 0.64 & 0.62 \\
\hline
\end{tabular}

ATBR = Alto Taquari/Bolsão region; CGDR = Campo Grande-Dourados; SPPR = Western São Paulo-Paraná.

Nepomuceno et al. (2013) found correlations smaller than 0.80 , which indicated strong genotypeenvironment interaction, and demonstrated that classification of animals may vary between environments. This was also verified in the present study, where the merit order of the breeding bulls in the different environmental gradients changed the classification (Table 7).

The first two main components had a cumulative variance percentage sufficient to explain $99.99 \%$ variation among the regions. Despite the significant difference in the univariate analysis, W205 was the trait with the lowest importance for the differentiation of the regions. The variables that contributed the most to the first component $(\mathrm{Y}=0.54 \mathrm{WGBW}+$ $0.11 \mathrm{~W} 205+0.74 \mathrm{WG} 18+0.36 \mathrm{~W} 550)$ were the daily gains of pre- and post-weaning weight, as shown by the highest value of WGBW and WG18; and for the second component ( $\mathrm{Y}=0.79 \mathrm{WGBW}+$ $0.16 \mathrm{~W} 205-0.58 \mathrm{WG} 18-0.03 \mathrm{~W} 550)$, it was the weight gain from birth to weaning (WGBW). 
Table 7. Spearman correlation (obtained on the basis of the expected progeny differences (EPD) of the sires) and the number of sires in the two regions (pairs) evaluated $(\mathrm{N})$.

\begin{tabular}{|c|c|c|}
\hline \multirow{3}{*}{ Region } & \multicolumn{2}{|c|}{ Region } \\
\hline & CGDR & SSPR \\
\hline & \multicolumn{2}{|c|}{ WGBW } \\
\hline ATBR & $0.19 *(655)$ & $0.24 *(642)$ \\
\hline \multirow[t]{2}{*}{ CGDR } & & $0.29 *(867)$ \\
\hline & \multicolumn{2}{|c|}{ W205 } \\
\hline ATBR & $0.20 *(655)$ & $0.25^{*}(642)$ \\
\hline \multirow[t]{2}{*}{ CGDR } & & $0.29 *(867)$ \\
\hline & \multicolumn{2}{|c|}{ WG18 } \\
\hline ATBR & $0.24 *(655)$ & $0.22 *(642)$ \\
\hline \multirow[t]{2}{*}{ CGDR } & & $0.20 *(867)$ \\
\hline & \multicolumn{2}{|c|}{ W550 } \\
\hline ATBR & $0.31 *(655)$ & $0.28 *(642)$ \\
\hline CGDR & & $0.31 *(867)$ \\
\hline
\end{tabular}

*Statistically significant correlation $(\mathrm{P}<0,05)$; WGBW: birth weight at weaning; W205: adjusted weight to 205 days; WG18: weaning weight gain at 18 months of age; W550: adjusted weight to 550 days. ATBR = Alto Taquari/Bolsão region; CGDR = Campo Grande-Dourados; SPPR = Western São Paulo-Paraná.

Therefore, the weight gains of the animals in the regions were different. The use of daily weight gain as a selection criterion may be interesting to determine precocious animals before they reach the adult phase (COSTA et al., 2008; MALHADO et al., 2009). Thus, male bovine animals with greater performance of weight gain are kept for less time in pastures for finishing, and can be sent earlier for breeding or finishing in feedlot. This optimizes the production system, improve financial returns, and provide good animals for the market. Moreover, the female bovine animals may be used earlier for reproduction. Female bovine animals need good quality pastures to grow, and avoid first-calving dams fail to procreate again in the following year because of the food quality and quantity. Herds with high sexual precocity and fertility have greater availability of individuals for selection or sale, providing greater intensity of selection, genetic progress and profitability (GUIMARÃES et al., 2011).

The biplot dispersion graph showed the differences in cattle performance between regions
(Figure 1). ATBR had lower production rates; the mean Euclidean distance indicated low similarity between ATBR and CGDR (43.20), and ATBR and SPPR (29.24). CGDR and SPPR presented similarity of 17.84 .

The genetic trends over the years were positive. W205 had annual genetic gains of $0.24,0.15$, and $0.34 \mathrm{~kg}$; with annual genetic changes increases of $0.14 \%, 0.08 \%$ and $0.19 \%$, representing $6,3.8$ and $8.5 \mathrm{~kg}$ in the W205 averages, respectively for ATBR, CGDR and SPPR (Figure 2). There was a great variation in the genetic gain of the animals, indicating a higher selection pressure in the western São Paulo/Paraná, with an additional $8.5 \mathrm{~kg}$ per year.

The annual genetic gain for W550 were 0.97; 0.29 and $0.55 \mathrm{~kg}$, with annual genetic change increases of $0.33 \% ; 0.09 \%$ and $0.18 \%$, representing $24.25 ; 7.25$ and $13.75 \mathrm{~kg}$ in the W550 averages, respectively for ATBR, CGDR and SPPR (Figure 3). 
Figure 1. Biplot dispersion graph for weight gain from birth to weaning (WGBW), adjusted weight to 205 days (W205), weight gain from weaning to 18 months of age (WG18) and adjusted weight to 550 days (W550) of Nellore cattle raised in the Alto Taquari/Bolsão (ATBR), Campo Grande/Dourados (CGDR) and western São Paulo/Paraná (SPPR) regions, in Brazil.

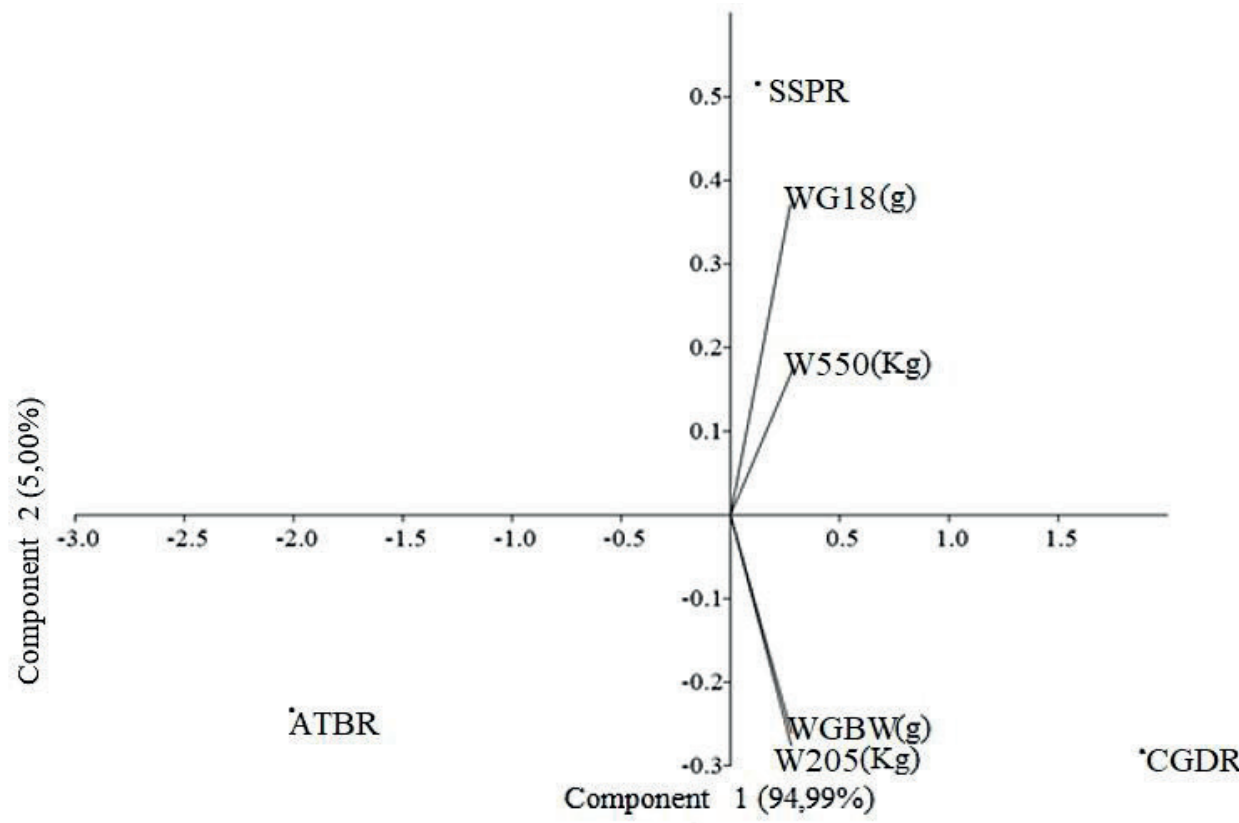

Figure 2. Genetic trends based on the breed value (BV) for the adjusted weight to 205 days (W205), fitted to the regression of the observed values, according to the year of birth of Nellore animals raised in the Alto Taquari/Bolsão $(\mathrm{ATBR})\left(\mathrm{BV}=\mathrm{y}=0.2203 \mathrm{x}-2.7877 ; \mathrm{R}^{2}=76.85 \%\right)$, Campo Grande/Dourados $(\mathrm{CGDR})(\mathrm{BV}=\mathrm{y}=0.2225 \mathrm{x}-1.0781$; $\left.\mathrm{R}^{2}=67.25 \%\right)$, and western São Paulo/Paraná (SPPR) $\left(\mathrm{BV}=\mathrm{y}=0.3187 \mathrm{x}-3.199 ; \mathrm{R}^{2}=92.54 \%\right)$ regions, in Brazil.

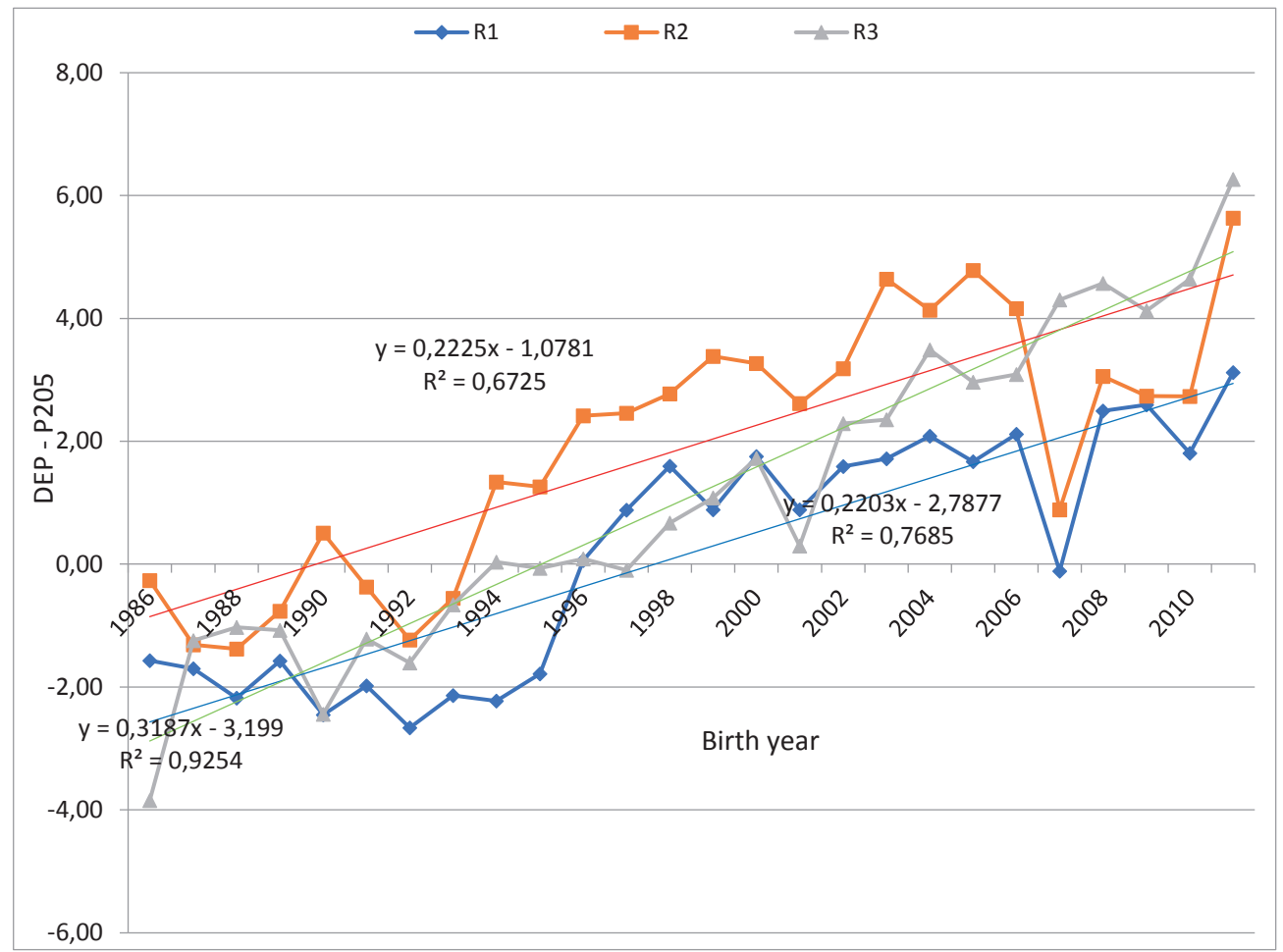

Semina: Ciências Agrárias, Londrina, v. 39, n. 1, p. 349-362, jan./fev. 2018 
Figure 3. Genetic trends based on the breed values (BV) for the adjusted weight to 550 days (W205), fitted to the regression of the observed values, according to the year of birth of Nellore animals raised in the Alto Taquari/Bolsão (ATBR) $\left(B V=y=0.8776 \mathrm{x}-12.859 ; \mathrm{R}^{2}=81.84 \%\right.$ ), Campo Grande/Dourados (CGDR) $(\mathrm{BV}=\mathrm{y}=0.5103 \mathrm{x}-2.8402$; $\left.\mathrm{R}^{2}=55.99 \%\right)$, and western São Paulo/Paraná (SPPR) $\left(\mathrm{BV}=\mathrm{y}=0.5384 \mathrm{x}-5.4747 ; \mathrm{R}^{2}=84.99 \%\right)$ regions, in Brazil.

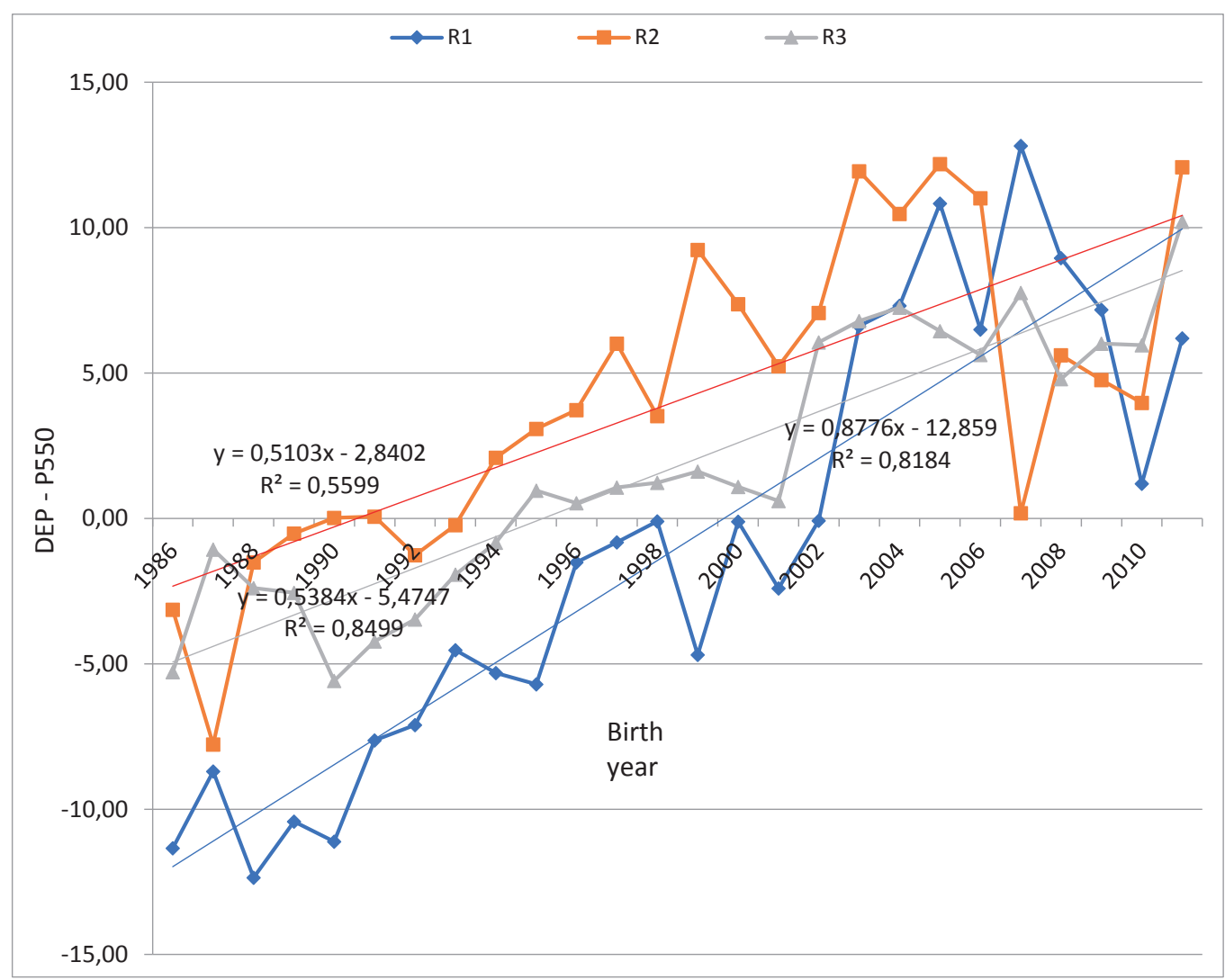

The annual genetic gain for WGBW were 0.0011 ; 0.0006 and $0.0015 \mathrm{~kg}$, with annual genetic change increases of $0.16 \%, 0.08 \%$ and $0.21 \%$, representing $0.028,0.015$ and $0.038 \mathrm{~kg}$ in the WGBW averages, respectively for ATBR, CGDR and SPPR. The annual genetic gain for WG18 were 0.0021; 0.0002 and $0.0005 \mathrm{~kg}$, with annual genetic change increases of $0.6 \%, 0.05 \%$ and $0.13 \%$, representing the difference of $0.053,0.005$ and $0.013 \mathrm{~kg}$ in the WG18 averages, respectively for ATBR, CGDR and SPPR.

The annual genetic changes were below the lower limit of the range proposed by Smith (1985), in which the annual genetic change can reach $1 \%$ to $3 \%$ population mean. However, Ferraz Filho et al. (2002) evaluated Tabapuã cattle and found increment of annual genetic change of $0.08 \%$, $0.09 \%$ and $0.10 \%$ in the W205, P365 and W550 averages over the years.

Thus, considering the observed and estimated gains, the genetic gain evolved over the years, with estimates ranged from -21 to 14.6 (ATBR), -4.9 to 26.6 (CGDR), and -16.9 to 27 (SPPR) for WGBW; 40 to 35 (ATBR), -17.6 to 18.2 (CGDR), and -8 to 12 (SPPR) for WG18; -1.6 to 3 (ATBR), -0.2 to 5.6 (CGDR) and -3.8 to 6.2 (SPPR) for W205; and -11.3 to 12.8 (ATBR) 7.7 to 12.1 (CGDR), and -5.5 to 10.2 (SPPR) for W550. This indicates the high genetic variability within the years studied in the different regions, and the consequent genetic and phenotypic improvement over the 25 years studied. 


\section{Conclusion}

The breed values of the traits increased over the years. The weight gain of the animals showed greater importance for the differentiation of the regions. The occurrence of genotype-environment interaction was confirmed for the traits evaluated, thus, the selected sire with superior breed value for one region might not be the best for others.

\section{References}

AMBROSINI, D. P.; MALHADO, C. H. M.; MARTINS FILHO, R.; CARNEIRO, P. L. S. Genotype x environment interaction via models of reaction norms for growth traits in Nellore cattle. Pesquisa Agropecuária Brasileira, Brasília, v. 51, n. 2, p. 177-186, 2016.

ARRUDA, Z. J.; SUGAI, Y. Regionalization of cattle raising in Brazil. Campo Grande: EMBRAPA-CNPGC, 1994. $144 \mathrm{p}$.

BOLDMAN, K. G.; KRIESE, L. A.; VAN VLECK, L. D.; VAN TASSELL, C. P.; KACHMAN, S. D. A manual for use of MTDFREML, a set of programs to obtain estimates of variances and covariances [DRAFT]. Lincoln: Department of Agriculture, Agricultural Research Service, 1995. $120 \mathrm{p}$.

CARVALHO, C. V. D.; BITTENCOURT, T. C. C.; LÔBO, R. B.; PINTO, L. F. B.; NASCIMENTO, M. C. Genotype-environment interaction on the weights at 205 and 365 days of age in Nellore cattle in different regions of Brazil. Revista Brasileira de Saúde Produção Animal, Salvador, v. 14, n. 1, p. 10-20, 2013.

CONCEIÇÃO, F. M.; FERRAZ FILHO, P. B.; SILVA, L. O. C.; BRAGANÇA, V. L. C.; SOUZA, J. C. Environmental factors that influence the weaning weight, year weight and weight at 18- months in Nellore Mocho cattle in the southwest of Mato Grosso do Sul - Brazil. Archives of Veterinary Science, Curitiba, v. 10, n. 2, p. 157-165, 2005.

COSTA, G. Z.; QUEIROZ, S. A.; OLIVEIRA, J. A.; FRIES, L. A. Genetic and phenotypic estimates of visual score and average daily gain from birth to weaning of cattle used to form the Brangus breed. ARS Veterinária, Jaboticabal, v. 24, n. 3, p. 172-176, 2008.

DIOP, M., DODENHOFF, J., Van VLECK, L. D. Estimates of direct, maternal and grandmaternal genetic effects for growth traits in Gobra cattle. Genetics and Molecular Biology, Ribeirão Preto, v. 22, n. 3, p. 363367, 1999.
FERRAZ FILHO, P. B. F.; RAMOS, A.; SILVA, L. O. C.; SOUZA, J. C.; ALENCAR, M. M.; MALHADO, C. H. $M$. Genetic trends of the direct and maternal effects for weaning and post-weaning weights of Tabapuã Cattle in Brazil. Revista Brasileira de Zootecnia, Brasilia, v. 31, n. 2, p. 635-640, 2002.

FERNANDES, H. D.; FERREIRA, G. B. Estudo comparativo de sete diferentes modelos estatísticos para a característica ganho de peso em bovinos de corte. Revista Brasileira de Zootecnia, Viçosa, v. 29, n. 5, p. 1340-1348, 2000.

FRIDRICH, A. B.; SILVA, M. A.; VALENTE, B. D.; SOUSA, J. E. R.; CORREAA, G. S. S.; FERREIRA, I. C.; VENTURA, R. V.; SILVA, L. O. C. Genotype by environment interaction and genetic parameter estimates for 205 and 365 body weight of Nellore cattle. Arquivo Brasileiro de Medicina Veterinária e Zootecnia, Belo Horizonte, v. 60, n. 4, p. 917-925, 2008.

GUIMARÃES， J. D.; GUIMARÃES， S. E. F.; SIQUEIRA, J. B.; PINHO, R. O.; ELER, J. P.; FERRAZ, J. B. S.; SILVA, R. M.; BORGES, J. C. Selection and reproductive management of zebu bulls. Revista Brasileira de Zootecnia, Viçosa, MG, v. 40, n. 1, p. 379388, 2011.

HAMMER, Q.; HARPER, D. A. T.; RYAN, P. D. PAST: Paleontological Statistics Software Package for Education and Data Analysis Palaeontol. Olso: Electronica, 2001. v. 4, $252 \mathrm{p}$.

HENDERSON, C. R. Comparison of alternative sire evaluation methods. Journal of Animal Science, Champaign, v. 41, n. 3, p. 760-770, 1975.

HERRERO, M.; THORTON, P. K.; NOTENBAERT, A. M.; WOOD, S.; MSANGI, S.; FREEMAN, H. A.; BOSSIO, D.; DIXON, J.; PETERS, M.; VAN DE STEEG, J.; LYNAM, J.; RAO, P. P.; MACMILLAN, S.; GERARD, B.; MCDEMOTT, J.; SERÉ, C. E.; ROSEGRANT, M. Smart investments in sustainable food production: revisiting mixed crop-livestock systems. Science, Washington, v. 327, n. 5967, p. 822-825, 2010.

JOOST, S.; COLLI, L.; BARET, P. V. Integrating georeferenced multiscale and multidisciplinary data for the management of biodiversity in livestock genetic resources. Animal Genetics, New York, v. 41, n. p. 47-63, 2010. Supplement 1.

LACERDA, J. J. D.; CARNEIRO, P. L. S.; MARTINS FILHO, R.; MALHADO, C. H. M. Parameters and genetic trends for growth traits of Nellore cattle from Bahia state using bayesian inference. Revista Brasileira de Saúde Produção Animal, Salvador, v. 15, n. 1, p. 1019, 2014. 
LIRA, T. S.; PEREIRA, L. S.; NEPOMUCENO, L. L.; ALEXANDRINO, E.; LOPES, F. B.; LÔBO, R. B.; FERREIRA, J. L. Genotype-environment interaction of post-weaning weights in Nellore from Maranhão, Mato Grosso and Pará States. Acta Veterinária Brasílica, Mossoró, v. 7, n. 4, p. 282-287, 2013.

LOPES, F. B.; SANTOS G. C. J.; MARQUES, E. G.; SILVA, M. C.; FERREIRA, J. L. Genetic trends for traits related to the growth rate in Nellore cattle from Northern Brazil. Revista Ciência Agronômica, Fortaleza, v. 43, n. 2, p. 362-367, 2012.

MALHADO, C. H. M.; CARNEIRO, P. L. S.; MARTINS FILHO, R.; PEREIRA, D. G.; AFFONSO, P. R. A. M.; AZEVEDO, D. M. M. R.; SOUZA, J. C. Parameters and genetics trends for maturation rate and asymptotic weight in Nellore cattle from Bahia State. Revista Brasileira de Saúde e Produção Animal, Salvador, v. 10, n. 2, p. 245255, 2009.

MALHADO, C. H. M.; CARNEIRO, P. L. S.; PEREIRA, D. G.; MARTINS FILHO, R. Genetic progress and population structure in Nellore cattle in Bahia State, Brazil. Pesquisa Agropecuária Brasileira, Brasilia, v. 43, n. 9, p. 1163-1169, 2008.

MALHADO, C. H. M.; LÔBO, R. N. B.; MARTINS FILHO, R.; FACÓ, O.; AZEVÊDO, D. M. M. R. Efeito da incorporação da covariância entre os efeitos direto e materno sobre a análise para a característica dias para ganhar $160 \mathrm{Kg}$. Brazilian Journal of Veterinary Research and Animal Science, São Paulo, v. 41, n. 1, p. 14-19, 2004.

MARQUES, E. G.; MAGNABOSCO, C. U.; LOPES, F. B.; SILVA, M. C. estimate the genetic parameters of growth characteristics, carcass and scrotal perimeter in Nellore evaluated in weight gain performance tests in feedlot. Bioscience Journal, Uberlândia, v. 29, n. 1, p. 159-167, 2013.

MEYER, K. Bias and sampling covariances of estimates of variance components due to maternal effects. Genetics Selection Evolution, Armidale, v. 24, p.487-509, 1992.

MOITA NETO, J. M.; MOITA, G. C. An introduction analysis exploratory multivariate date. Química Nova, São Paulo, v. 21, n. 4, p. 467-469, 1998.

NEPOMUCENO, L. L.; LIRA, T. S.; LOPES, F. B.; LÔBO, R. B.; FERREIRA, J. L. Genotype-environment interaction for maternal effect traits in Nellore cattle from Maranhão, Mato Grosso and Pará States. Revista Brasileira de Saúde Produção Animal, Salvador, v. 14, n. 2, p. 269-276, 2013.
PASSAFORO, T. L.; FRAGOMENI, B. O.; GONÇALVES, D. R.; MORAES, M. M.; TORAL, F. L. B. Genetic analysis of body weight in a Nellore cattle herd. Pesquisa Agropecuária Brasileira, Brasília, v. 51, n. 2, p. 149-158, 2016.

PEDROSA, V. B.; ELER, J. P.; FERRAZ, J. B. S.; PINTO, L. F. B. Utilization of single-trait and multitrait models applied to genetic parameter estimation in Nellore Cattle. Arquivos Brasileiros de Medicina Veterinária e Zootecnia, Belo Horizonte, v. 66, n. 6, p. 1802-1812, 2014.

RAMOS, A. A.; MALHADO, C. H. M.; CARNEIRO, P. L. S.; AZEVEDO, D. M. M. R.; SOUZA, J. C. Selection criterions (GWB and D160) for growth velocity in beef Buf. Ciência Animal Brasileira, Goiânia, v. 10, n. 3, p. 776-782, 2009.

REZENDE, M. P. G.; FERRAZ, P. C.; CARNEIRO, P. L. S.; MALHADO, C. H. M. Phenotypic diversity in Jafarabadi buffaloes, Murrah and Mediterranean. Pesquisa Agropecuária Brasileira, Brasília, v. 52, n. 8, p. 663-669, 2017.

REZENDE, M. P. G.; SILVEIRA, M. V.; SILVA, R. M.; SILVA, L. O. C.; GONDO, A.; RAMIRES, G. G.; SOUZA, J. C. Pre and post weaning weight gain in Nellore cattle raised in the Pantanal, Mato Grosso do Sul, Brazil). Ciência Animal, Fortaleza, v. 24, n. 2, p. 20-27, 2014.

REZENDE, M. P. G.; SOUZA, J. C.; MOTA, M. F.; OLIVEIRA, N. M.; JARDIM, R. J. D. Conformation index of horses of different genetic groups. Ciência Animal Brasileira, Goiânia, v. 17, n. 3, p. 316-326, 2016.

SANTOS, G. C. J.; LOPES, F. B.; MARQUES, E. G.; SILVA, M. C.; CAVALCANTE, T. V.; FERREIRA J. L. Genetic trend for adjusted weight at 205, 365 and 550 days of age of Nellore cattle from Northern Brazil. Acta Scientiarum. Animal Sciences, Maringa, v. 34, n. 1, p. $97-$ 101, 2012.

SCHAEFFER, L. R. Sire and cow evaluation under multiple trait models. Journal of Dairy Science, Champaign, v. 67, p.1567-1580, 1984.

STATISTICAL ANALYSIS SYSTEM INSTITUTE SAS Institute. Statistical analysis system: user's guide: statistics. Cary: SAS Institute, 2015.

SILVEIRA, M. V.; SOUZA, J. C.; SILVA, L. O. C.; FREITAS, J. A.; GONDO, A.; FERRAZ FILHO, P. B. Genotype by environment interaction on productive and reproductive traits of females of the Nellore breed. Archivos de Zootecnia, Córdoba, v. 63, n. 241, p. 223226, 2014. 
SMITH, C. Rates of genetic change in farm livestock. Research Development Agricultural, v. 1, n. 2, p. 79-85, 1985.

SOUZA, J. C.; MALHADO, C. H. M.; SILVA, L. O. C.; LEAL, T. L.; GOMES, C. M.; JACINTO E. J. FERRAZ FILHO, P. B. Parameters and genetic trends of Guzera Cattle in Mata and Agreste micro-region in northeast of Brazil. Revista Acadêmica: Ciências Agrárias e Ambientais, Curitiba, v. 2, n. 2, p. 47-52, 2004.

SOUZA, J. C.; SILVA, C. S. L. O.; SIMÕES, G. H.; MOSER, J. T.; OSTAPECHEN, J.; PINTO, N. P. H.; RUVIERO, V.; MALHADO, M. C. H.; FERRAZ FILHO, B. P.; FREITAS. J. A.; SERENO, J. R. B. Environmental and genetic trends for productive traits in Nellore cattle. Asociación Latinoamericana de Producción Animal, Maracaibo. v. 16, n. 2, p. 85-90, 2008.

SOUZA, J. C.; RAMOS, A.A.; SILVA, L. O. C.; EUCLIDES FILHO, K.; ALENCAR, M. M.; WECHSLER, F. S.; FERRAZ FILHO, P. B. Fatores do ambiente sobre o peso ao desmame de bezerros da raça nelore em regiões tropicais brasileiras. Ciência Rural, Santa Maria, v. 30, n. 5, p. 881-885, 2000.

SOUZA, J. C.; GADINI, C. H.; SILVA, L. O. C.; RAMOS, A. A.; ALENCAR, M. M.; FERRAZ FILHO, P. B.; VLECK, L. D. V. Estimates of genetic parameters and evaluation of genotype $\mathrm{x}$ environment interaction for weaning weight in Nellore cattle. Archivos Latinoamericanos de Producción Animal, Maracaibo, v. 11, n. 2, p. 94-100, 2003.

SOUZA, J. C.; RAMOS, A. A.; SILVA, L. O. C.; EUCLIDES FILHO, K.; ALENCAR, M. M.; WECHSLER, F.; GADINI, C. H.; VLECK, L. D. V. Effect of genotype $\mathrm{x}$ environment interaction on weaning weight of Nellore calves raised in four different regions of Brazil. In: WORLD CONGRESS ON GENETICS APPLIED TO LIVESTOCK PRODUCTION, 6., 1998, Armidale. Proceedings... Armidale, 1998. v. 23. p. 196198. 
